\title{
REUSE AND CHARACTERIZATION OF WASTE KAOLIN, GRANITE AND MARBLE IN THE PRODUCTION OF CERAMIC COMPOSITE
}

\author{
Sales, J. L.*; Morais, C.R.S.; Lima, L.M.R.; Cibalde, J.C.B.; Targino, E.K.L.A. \\ Departamento de Pós-Graduação em Engenharia de Materiais, Universidade Federal de Campina Grande - UFCG, , Campina Grande, PB, \\ Brasil
}

*josyanne27@yahoo.com.br

\begin{abstract}
The objective of this work is to benefit and characterize waste kaolin, marble and granite studying thermal and spectroscopic properties, but also evaluate their behavior in the manufacture of ceramic composites. The residues were benefited through the process of dry grinding in mill gauges and passed through sieve $0.074 \mathrm{~mm}$ (No. 200 ABNT). Tests of physicochemical characterization (X-ray fluorescence and X-ray diffraction) and thermal (differential thermal analysis and thermogravimetry) were performed. The composites were made using equal amounts of waste and a previously prepared resin. The results showed that these residues had satisfactory properties, allowing its reuse.
\end{abstract}

